\title{
Genomic behavior of hybrid combinations between elephant grass and pearl millet
}

\author{
Fernando Ferreira Leão(1), Lisete Chamma Davide ${ }^{(2)}$, José Marcello Salabert de Campos(3), \\ Antonio Vander Pereira ${ }^{(4)}$ and Fernanda de Oliveira Bustamante ${ }^{(2)}$
}

\begin{abstract}
(1)Universidade Federal de Tocantins, Campus Gurupi, Caixa Postal 66, CEP 77402-970 Gurupi, TO, Brazil. E-mail: ferleao@hotmail.com (2) Universidade Federal de Lavras, Departamento de Biologia, Caixa Postal 3037, CEP 37200-000 Lavras, MG, Brazil. E-mail: lisete.ufla@gmail.com, fobustamante@gmail.com ${ }^{(3)}$ Universidade Federal de Juiz de Fora, Instituto de Ciências Biológicas, Departamento de Biologia, CEP 36036-900 Juiz de Fora, MG, Brazil. E-mail: jose.campos@ufjf.edu.br (4)Embrapa Gado de Leite, Rua Eugênio do Nascimento, no 610, CEP 36038-330 Juiz de Fora, MG, Brazil. E-mail: avanderp@cnpgl.embrapa.br
\end{abstract}

Abstract - The objective of this work was to evaluate the genomic behavior of hybrid combinations between elephant grass (Pennisetum purpureum) and pearl millet (P. glaucum). Tetraploid (AAA'B) and pentaploid (AA'A'BB) chromosome races resulting from the backcross of the hexaploid hybrid to its parents elephant grass (A'A'BB) and pearl millet (AA) were analyzed as to chromosome number and DNA content. Genotypes of elephant grass, millet, and triploid and hexaploid induced hybrids were compared. Pentaploid and tetraploid genomic combinations showed high level of mixoploidy, in discordance with the expected somatic chromosome set. The pentaploid chromosome number ranged from 20 to 34, and the tetraploid chromosome number from 16 to 28 . Chromosome number variation was higher in pentaploid genomic combinations than in tetraploid, and mixoploidy was observed among hexaploids. Genomic combinations $4 \mathrm{x}$ and $5 \mathrm{x}$ are mixoploid, and the variation of chromosome number within chromosomal race $5 \mathrm{x}$ is greater than in $4 \mathrm{x}$.

Index terms: Pennisetum glaucum, Pennisetum purpureum, DNA content, interspecific hybrids, mixoploidy.

\section{Comportamento genômico de combinações híbridas entre capim-elefante e milheto}

\begin{abstract}
Resumo - O objetivo deste trabalho foi avaliar o comportamento genômico de combinações híbridas resultantes do cruzamento entre capim-elefante (Pennisetum purpureum) e milheto (P. glaucum). Raças cromossômicas tetraploides (AAA'B) e pentaploides (AA'A'BB), resultantes do retrocruzamento do híbrido hexaploide com seus parentais capim-elefante (A'A'BB) e milheto (AA), foram avaliadas quanto ao número cromossômico e ao conteúdo de DNA. Foram comparados os genótipos de capim-elefante, milheto e de híbridos triploides e hexaploides induzidos. As combinações genômicas pentaploides e tetraploides mostraram elevado grau de mixoploidia, em desacordo com o complemento cromossômico somático esperado. O número cromossômico dos pentaploides variou de 20 a 34, e o dos tetraploides de 16 a 28. A variação do número cromossômico foi maior nas combinações genômicas pentaploides do que nas tetraploides, e a mixoploidia foi verificada entre hexaploides. As combinações genômicas 4x e 5x são mixoploides, e a variação do número de cromossomos na raça cromossômica $5 \mathrm{x}$ é maior do que na $4 \mathrm{x}$.
\end{abstract}

Termos para indexação: Pennisetum glaucum, Pennisetum purpureum, conteúdo de DNA, híbridos interespecíficos, mixoploidia.

\section{Introduction}

The genus Pennisetum is widely used in grass forage production. Among the species with an important role in forage grass production, elephant grass (Pennisetum purpureum Schumach; $2 \mathrm{n}=4 \mathrm{x}=28$, $\left.\mathrm{A}^{\prime} \mathrm{A}^{\prime} \mathrm{BB}\right)$ and pearl millet (P. glaucum L.R.Br.; $2 \mathrm{n}=2 \mathrm{x}=14$, AA) are the ones of greatest economic importance within the genus. Hybrid production between these two species $\left(2 \mathrm{n}=3 \mathrm{x}=21, \mathrm{AA}^{\prime} \mathrm{B}\right)$ is a common strategy used in elephant grass breeding programs to combine the most favorable millet characteristics (resistance to drought, tolerance to diseases, and seed size) with the hardness, aggressiveness, and high dry matter production of elephant grass (Pereira et al., 2003). However, the sterility of the triploid hybrid is a limiting factor of this strategy.

Induction of chromosome duplication has been used as an alternative to restore hybrid fertility, producing

Pesq. agropec. bras., Brasília, v.46, n.7, p.712-719, jul. 2011 
fertile hexaploids with $2 \mathrm{n}=6 \mathrm{x}=42$ (Abreu et al., 2006; Barbosa et al., 2007; Bustamante, 2009; Campos et al., 2009). Additionally, mixoploidy with cells containing between 14 and 42 chromosomes has been reported in these experiments.

New genomic combinations or chromosomal races have also been obtained by backcrossing the hexaploid hybrid with its tetraploid (elephant grass) and diploid (millet) parents, producing pentaploid $(5 \mathrm{x})$ and tetraploid $(4 \mathrm{x})$ hybrids, respectively. However, there is no known information on the cytogenetic behavior of the genotypes obtained. For instance, there is still the need to determine if hybrids $4 \mathrm{x}$ and $5 \mathrm{x}$ can be characterized as mixoploids or if there is the possibility to find genotypes with a more stable number of chromosomes.

Synthetic hybrids commonly display phenotypic and genetic instability as a result of nuclear conflicts, such as chromosome and DNA fragment elimination (Ozkan et al., 2003; Ma et al., 2004; Ma \& Gustafson, 2006). Genome stability can be evaluated by chromosome counting, a very accurate method for the identification of the exact chromosome number of duplicated plants, and
DNA content can be assessed by flow cytometry, a method frequently used to screen ploidy in a large number of plants (Bustamante, 2009; Campos et al., 2009).

The objective of this work was to evaluate the genomic behavior of hybrid combinations between elephant grass and pearl millet.

\section{Materials and Methods}

Fifteen genotypes of Pennisetum spp. provided by the active germplasm bank of Embrapa Gado de Leite, Juiz de Fora, MG, Brazil, were analyzed (Table 1). Thirteen genotypes were vegetatively propagated (clones), and M-36 millet and 'Paraíso' populations were propagated by seeds and by a seed mixture of seven different plants, respectively. Hexaploid genotypes were obtained by inducing chromosome duplication in the genomic combination HCM-6x-1, from six different clones, and HCM-6x-2, from seven different clones.

Chromosome counting was performed on genomic combinations $4 \mathrm{x}$ and $5 \mathrm{x}$, and cultivar Paraíso and HCM-6x-2, both hexaploids, were

Table 1. Expected ploidy and genomic constitution of the Pennisetum spp. analyzed.

\begin{tabular}{|c|c|c|}
\hline Identification & Genotype & Expected ploidy and genomic constitution \\
\hline M-36 & Pearl millet 36 (millet population) & $2 \mathrm{x}, \mathrm{AA}$ \\
\hline CNPGL 92-176-3 & 'Merker' (elephant grass clone) x CMS 464 (millet population) & $3 \mathrm{x}(4 \mathrm{x}$ vs. $2 \mathrm{x}), \mathrm{AA}^{\prime} \mathrm{B}$ \\
\hline CNPGL 94-49-6 & 'Pasto Panamá' (elephant grass clone) x Pearl millet 38 (millet population) & $3 \mathrm{x}(4 \mathrm{x}$ vs. $2 \mathrm{x}), \mathrm{AA}^{\prime} \mathrm{B}$ \\
\hline 'Pioneiro' & 'Três Rios' (elephant grass clone) x 'Merker' (elephant grass clone) & $4 \mathrm{x}, \mathrm{A}^{\prime} \mathrm{A}^{\prime} \mathrm{BB}$ \\
\hline 'Cameroon' & 'Cameroon' (elephant grass clone) & $4 \mathrm{x}, \mathrm{A}^{\prime} \mathrm{A}^{\prime} \mathrm{BB}$ \\
\hline HCM-4x-1 & $\begin{array}{l}\text { Hexaploid } 165 \text { (elephant grass hexaploid clone x pearl millet) x Pearl millet } 36 \\
\text { (millet population) }\end{array}$ & $4 \mathrm{x}(6 \mathrm{x}$ vs. $2 \mathrm{x}), \mathrm{AAA}^{\prime} \mathrm{B}$ \\
\hline HCM-4x-2 & $\begin{array}{l}\text { Hexaploid } 165 \text { (elephant grass hexaploid clone x pearl millet) x Pearl millet } 36 \\
\text { (millet population) }\end{array}$ & $4 \mathrm{x}(6 \mathrm{x}$ vs. $2 \mathrm{x}), \mathrm{AAA}^{\prime} \mathrm{B}$ \\
\hline HCM-4x-3 & $\begin{array}{l}\text { 'Paraíso' (hexaploid population of elephant grass } \mathrm{x} \text { pearl millet) x Pearl millet MSI } \\
\text { (millet population) }\end{array}$ & $4 \mathrm{x}(6 \mathrm{x}$ vs. $2 \mathrm{x}), \mathrm{AAA}^{\prime} \mathrm{B}$ \\
\hline HCM-4x-4 & $\begin{array}{l}\text { Hexaploid 07-3 (hexaploid population of elephant grass x pearl millet) x Pearl millet } \\
\qquad 35 \text { (millet population) }\end{array}$ & $4 \mathrm{x}(6 \mathrm{x}$ vs. $2 \mathrm{x}), \mathrm{AAA}^{\prime} \mathrm{B}$ \\
\hline HCM-5x-1 & $\begin{array}{l}\text { CNPGL 96-27-3 (elephant grass clone) x 'Paraíso' (hexaploid population of elephant } \\
\text { grass x pearl millet) }\end{array}$ & $5 \mathrm{x}(4 \mathrm{x}$ vs. $6 \mathrm{x}), \mathrm{AA}^{\prime} \mathrm{A}^{\prime} \mathrm{BB}$ \\
\hline HCM-5x-2 & $\begin{array}{l}\text { CNPGL 96-27-3 (elephant grass clone) x 'Paraíso' (hexaploid population of elephant } \\
\text { grass x pearl millet) }\end{array}$ & $5 \mathrm{x}(4 \mathrm{x}$ vs. $6 \mathrm{x}), \mathrm{AA}^{\prime} \mathrm{A}^{\prime} \mathrm{BB}$ \\
\hline HCM-5x-3 & $\begin{array}{l}\text { CNPGL 96-27-3 (elephant grass clone) x 'Paraíso' (hexaploid population of elephant } \\
\text { grass x pearl millet) }\end{array}$ & $5 \mathrm{x}(4 \mathrm{x}$ vs. $6 \mathrm{x}), \mathrm{AA}^{\prime} \mathrm{A}^{\prime} \mathrm{BB}$ \\
\hline 'Paraíso' & 'Paraíso' (hexaploid population of elephant grass x pearl millet) & $6 \mathrm{x}, \mathrm{AAA}^{\prime} \mathrm{A}^{\prime} \mathrm{BB}$ \\
\hline HCM-6x-1 & Hexaploid 07-1 (hexaploid population of elephant grass $x$ pearl millet) & $6 \mathrm{x}, \mathrm{AAA}^{\prime} \mathrm{A}^{\prime} \mathrm{BB}$ \\
\hline HCM-6x-2 & Hexaploid 07-2 (hexaploid population of elephant grass x pearl millet) & $6 \mathrm{x}, \mathrm{AAA} \mathrm{A}^{\prime} \mathrm{B} B \mathrm{~B}$ \\
\hline
\end{tabular}

HCM, hybrid between elephant grass and pearl millet. 
used for comparison. All genotypes were evaluated by flow cytometry in order to determine DNA content.

The methodology proposed by Techio (2002) was used for chromosome counting. Slide analyses were performed using a bright field microscope (Leica DMLS, Wetzlar, Germany), equipped with a microcamera Nikon Digital Sight DS-Fi1, (Nikon Digital, Tokyo, Japan) for scanning images. Different metaphases (between 41 and 100) were obtained from at least five slides for each genotype. Analysis of variance was performed to estimate the significant differences between genomic combinations $4 \mathrm{x}$ and $5 \mathrm{x}$.

For DNA content, three samples of each genotype were analyzed, and 20 to $30 \mathrm{mg}$ of young leaf tissue were used for each sample. The same amount of young leaf material of Glycine max L. was used as an external standard reference. Nuclear suspension was stained with propidium iodide, and ten thousand nuclei were analyzed according to Doležel (1997). The analyses were performed on a FACSCalibur cytometer (BD Biosciences, San Jose, CA, USA), and the histograms were obtained using the CellQuest software (BD Biosciences, San Jose, CA, USA); the analyses were processed with WinMDI 2.8 (2009). Nuclear DNA content (pg) was normalized to the $\mathrm{G} 1$ peak of the standard reference G. $\max (2.50 \mathrm{pg})$ (Doležel et al., 2007).

The DNA content of elephant grass (4.54 pg) and pearl millet (4.75 pg) proposed by Campos et al. (2009) was used as a standard.

\section{Results and Discussion}

Since $\mathrm{x}=7$ is the basic number of chromosomes for elephant grass and millet, the expected chromosome number of tetraploid, pentaploid, and hexaploid hybrids was 28,35 and 42 , respectively. However, all genomic combinations showed variable levels of mixoploidy (Figure 1 and Table 2), and the number of cells observed with the full chromosome complement was reduced, although it was more frequent in the genomic combination HCM-6x-2.

The genomic combinations $4 \mathrm{x}$ and $5 \mathrm{x}$ were statistically different from each other regarding chromosome number (Table 3), and there is less variation on chromosomal race $4 \mathrm{x}$ than in $5 \mathrm{x}$, especially when taking the modal number into consideration (Table 2). Genomic changes in interspecific crosses indicate that the presence of two or more different genomes in the same nucleus leads to chromosomal rearrangements and to changes in the number and the distribution of DNA sequences, which may cause intergenic conflicts and chromosome loss (Comai, 2000; Riddle \& Birchler, 2003; Levy \& Feldman, 2004; Adams \& Wendel, 2005; Doyle et al., 2008; Bustamante, 2009; Campos et al., 2009).

Gernand et al. (2005), while evaluating hybrids from crosses between wheat and millet, observed uniparental chromosome elimination of millet with the formation of micronucleus and DNA heterochromatinization, with the chromosomes of pearl millet occupying a peripheral position in the interphase nuclei, being fragmented due to asynchrony during DNA replication. Likewise, Laurie \& Bennett (1989) and Mochida et al. (2004) found that millet chromosome elimination began soon after fertilization, when studying hybrids from the same cross.

As in the present study, Abreu et al. (2006) also observed mixoploidy. The authors found that, for triploid hybrids between pearl millet and elephant grass treated with antimitotic agents, there was duplication followed by chromosome elimination, confirmed by chromosome aberrations. Furthermore, $86.4 \%$ of the cells analyzed had a chromosome number other than 21. Similarly, Barbosa et al. (2007) observed that the chromosome number in the metaphases ranged from 14 to 42 in samples in which chromosome duplication was induced by antimitotic agents. Campos et al. (2009) reported that, from 480 triploid seedlings (hybrids of elephant grass and pearl millet) treated with colchicine to obtain hexaploids, 115 of the 200 survivors were mixoploids.

The nuclear DNA content previously determined for millet and elephant grass is 4.75 and $4.54 \mathrm{pg}$, respectively (Campos et al., 2009). Therefore, the triploid hybrid has an intermediate DNA amount of its parents $(4.65 \mathrm{pg})$, and chromosome duplication produces a hexaploid hybrid with $9.30 \mathrm{pg}$. The DNA content expected in genomic pentaploid combinations is derived from the sum of the parental gametic contents: $4.65 \mathrm{pg}$ for hexaploid 
hybrids plus $2.27 \mathrm{pg}$ for elephant grass, which totals $6.92 \mathrm{pg}$. For tetraploid genomic combinations, the expected value is $7.00 \mathrm{pg}$ ( $4.65 \mathrm{pg}$ for the hexaploid hybrid plus $2.38 \mathrm{pg}$ for pearl millet).
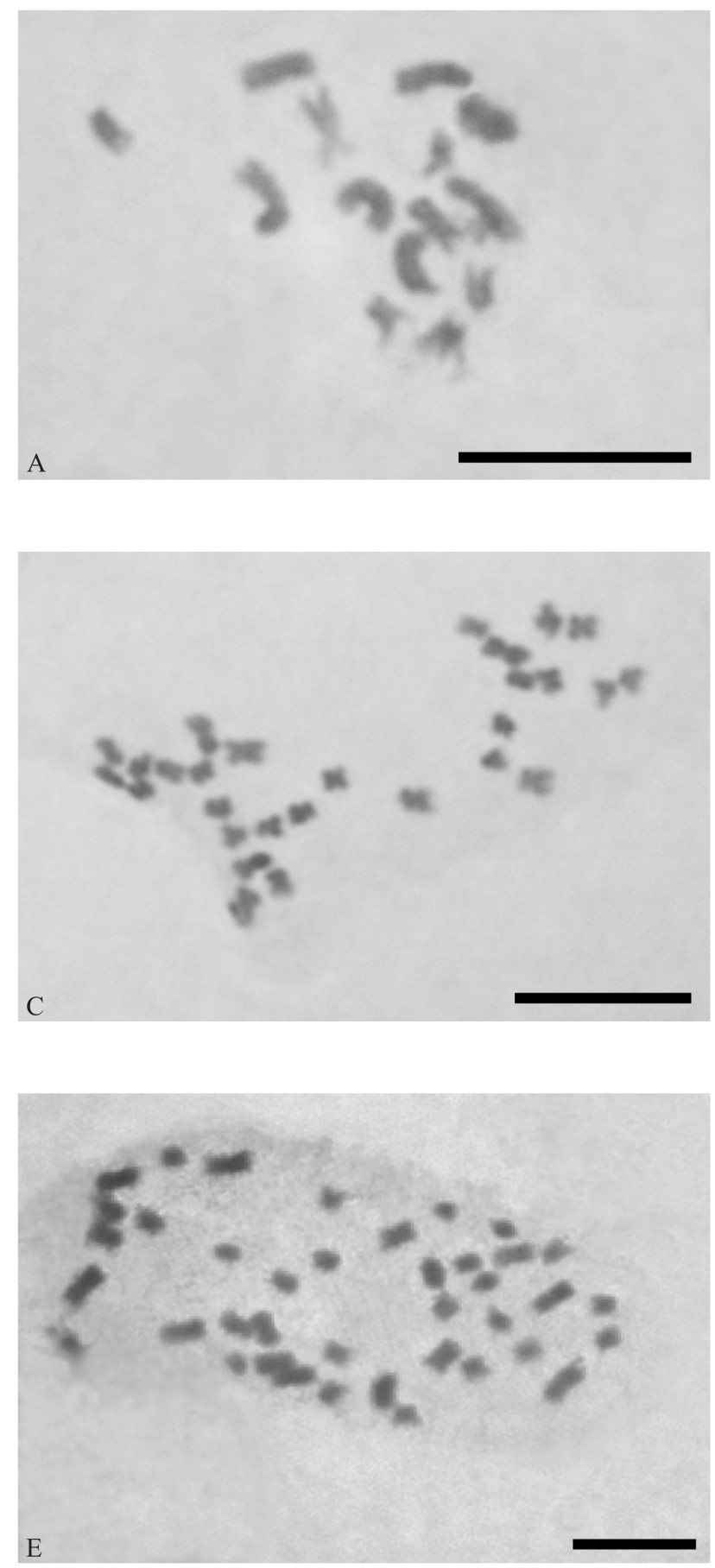

Variation in the DNA amount of the different genotypes was also observed (Table 4 and Figure 2). Elephant grass, represented by cultivars Pioneiro and Cameroon (Table 1), millet, and triploid
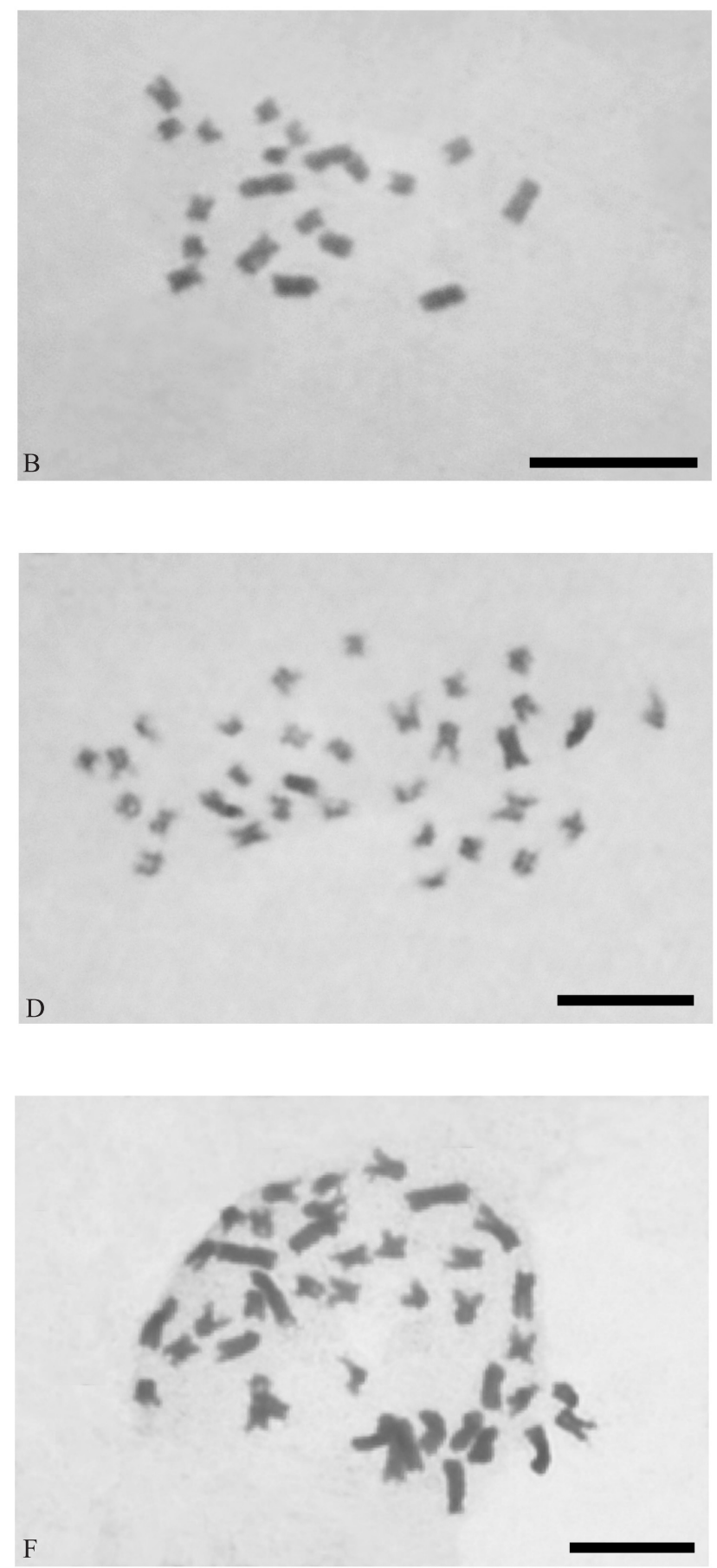

Figure 1. Chromosome number of the genomic combinations: A, HCM-6x-2 with 14 chromosomes; B, HCM-4x-3 with 20 chromosomes; C, HCM-5x-3 with 28 chromosomes; D, HCM-5x-3 with 32 chromosomes; E, HCM-6x-2 with 39 chromosomes; F, 'Paraíso' with 42 chromosomes. Bar: $10 \mu \mathrm{m}$. 
hybrids showed reduced loss of DNA content $(0$ to $2.16 \%$ ) when compared to chromosomal races $4 \mathrm{x}, 5 \mathrm{x}$, and to hybrids undergoing chromosome duplication (6x), which had loss in DNA content between 9.25 and $19 \%$. These results show that triploid genotypes are genetically and evolutionarily well established in comparison to genomic combinations $4 x, 5 x$, and $6 x$, whose greater reductions in DNA content indicate that they are still unstable and undergoing genomic reorganization, although it is likely that these new combinations may also achieve genotypic stability at some stage.

Different genomic combinations may also have influenced the differential loss on DNA content, since triploid genotypes and genomic combinations are clones, whereas hexaploids were obtained from a mixture of six and seven different clones of the elephant grass x pearl millet population (HCM-6x-1 and HCM-6x-2, respectively). The cultivar Paraíso was also obtained from a seed mixture of seven different plants, which may have contributed to the variation in DNA loss (Table 4).

The comparison between the genomic combinations $4 \mathrm{x}$ (AAA'B) and $5 \mathrm{x}$ (AA'A'BB) showed that the genomic constitution of pentaploids is very similar to that of elephant grass (A'A'BB), with only one extra dose of genome $A$, whereas tetraploids have two extra genomes ( $\mathrm{A}^{\prime}$ and $\mathrm{B}$ ), having the AA genome as the diploid millet (Table 4). The greatest reduction in DNA observed in chromosomal race $4 \mathrm{x}$ is probably a consequence of the increased genomic imbalance, in comparison to $5 \mathrm{x}$.

Since chromosomal race $4 \mathrm{x}$ showed less variation in chromosome number and greater loss of DNA when compared to chromosomal race $5 \mathrm{x}$, it is possible to infer that losses of chromosome segments in $4 \mathrm{x}$ were greater than in $5 \mathrm{x}$, and that more whole chromosomes were eliminated by chromosome race $5 \mathrm{x}$.

Recent studies have attempted to explain the mechanism of chromosome elimination in Pennisetum hybrids (Andrade-Vieira, 2010). Preliminary results showed non-preferential chromosome elimination. The chromosome elimination process could be a consequence of the aneuploidizant effect of colchicine - an alkaloid used for chromosome doubling -, resulting in random chromosome losses (Schoenlein et al., 2003; Caperta et al., 2006).

DNA loss for hexaploid genotypes has been previously reported by Campos et al. (2009). A great difference in DNA amount was observed in comparison to the standards between repetitions 1 and 2 of genomic combinations HCM-6x-1 and HCM-6x-2 (Table 4), which could be explained by the fact that these combinations were obtained from a mixture of different clones. Therefore, the stability of genotypes with a smaller DNA loss (repetition 1 of genotype HCM-6x-1 and repetition 2 of genotype HCM-6x-2) is possibly higher, and genomic conflicts and sequence loss are probably still more intense in repetition 2

Table 2. Number of metaphases analyzed, chromosome number variation, modal number, and percentage of metaphases with modal number of Pennisetum spp.

\begin{tabular}{lcccc}
\hline Genotype & Number of metaphases & Variation in chromosome number ${ }^{(1)}$ & Modal number & Metaphases with modal number (\%) \\
\hline HCM-4x-1 & 100 & $18(6)$ to $28(1)$ & 21 & 19.00 \\
HCM-4x-2 & 100 & $16(2)$ to $25(3)$ & 21 & 24.00 \\
HCM-4x-3 & 100 & $17(1)$ to 28(1) & 20 & 27.00 \\
HCM-4x-4 & 50 & $17(2)$ to 25(1) & 32 & 20.00 \\
HCM-5x-1 & 100 & $25(4)$ to 34(5) & 28 & 26.00 \\
HCM-5x-2 & 50 & $20(1)$ to 33(1) & 27 & 22.00 \\
HCM-5x-3 & 50 & $22(2)$ to 33(3) & 36 & 13.56 \\
'Paraíso' & 59 & $14(1)$ to 42(1) & 28 & 19.51 \\
HCM-6x-2 & 41 & $14(2)$ to 42(7) & \\
\hline
\end{tabular}

(1)Values between brackets represent the number of metaphases counted with the chromosome number determined. HCM, hybrid between elephant grass and pearl millet. 
of genotype HCM- $6 \mathrm{x}-1$ and in repetition 1 of genotype HCM-6x-2.

Cultivar Paraíso, obtained from a seed mixture of seven different plants, also varied regarding DNA content loss. However, the constrast between the two repetitions was lower than the loss observed in genotypes HCM-6x-1 and HCM-6x-2 (Table 4). The

Table 3. Analysis of variance for chromosome number of genomic combinations $4 \mathrm{x}$ and $5 \mathrm{x}$ of Pennisetum spp.

\begin{tabular}{lcc}
\hline Source of variation & Degrees of freedom & Mean square \\
\hline Genotypes & 10 & $180.24^{* *}$ \\
$5 \mathrm{x}$ & 3 & $23.70^{* *}$ \\
$4 \mathrm{x}$ & 6 & $4.03^{\text {ns }}$ \\
$5 \mathrm{x}$ vs. $4 \mathrm{x}$ & 1 & $1707.09^{* *}$ \\
Error & 99 & 2.96 \\
\hline CV $(\%)$ & - & 7.27 \\
\hline
\end{tabular}

${ }^{\mathrm{n}}$ Nonsignificant. **Significant by the $\mathrm{F}$ test, at $1 \%$ probability. greatest DNA losses (above 20\%) occurred among hexaploids, i.e., between individuals with the highest ploidy. Similar results have been reported for species of Artemisia (Pellicer et al., 2010). The authors observed that the increase in $2 \mathrm{C}$ values in polyploids is not proportional to ploidy level, since the $1 \mathrm{C}$ genome size tends to decrease significantly when high ploidy levels are achieved.

These results indicate that the chromosome distribution of genomic combinations $4 \mathrm{x}$ and $5 \mathrm{x}$ is similar to that of their parental $6 \mathrm{x}$, obtained by induced chromosome duplication. Mixoploidy, common to all these hybrids, confirms the difficulty in obtaining stable interspecific hybrids. However, the chromosome behavior of these genotypes does not decrease their forage potential, since the agronomic performance of chromosomal races $4 \mathrm{x}$ and, especially, $5 \mathrm{x}$ indicates that they have good potential use in breeding programs (Leão, 2009).

Table 4. Amount of DNA expected and observed, and percentage loss of DNA for genotype analysis.

\begin{tabular}{|c|c|c|c|c|c|}
\hline \multirow[t]{2}{*}{ Genotype } & \multirow[t]{2}{*}{ Repetition number } & \multirow[t]{2}{*}{ Expected ploidy } & DNA expected & DNA observed & \multirow{2}{*}{$\begin{array}{c}\text { DNA loss } \\
(\%)\end{array}$} \\
\hline & & & -------------- & |------------------- & \\
\hline Millet M-36 & 1 & $2 x$ & 4.75 & 4.72 & 0.00 \\
\hline \multirow[t]{2}{*}{ CNPGL 94-176-3 } & 1 & $3 x$ & 4.64 & 4.54 & 2.16 \\
\hline & 2 & $3 x$ & 4.64 & 4.56 & 1.72 \\
\hline \multirow[t]{2}{*}{ CNPGL 94-49-6 } & 1 & $3 x$ & 4.64 & 4.62 & 0.43 \\
\hline & 2 & $3 x$ & 4.64 & 4.66 & 0.00 \\
\hline \multirow[t]{2}{*}{ 'Pioneiro' } & 1 & $4 \mathrm{x}$ & 4.54 & 4.47 & 0.00 \\
\hline & 2 & $4 \mathrm{x}$ & 4.54 & 4.55 & 0.00 \\
\hline \multirow[t]{2}{*}{ 'Cameroon' } & 1 & $4 \mathrm{x}$ & 4.54 & 4.57 & 0.00 \\
\hline & 2 & $4 \mathrm{x}$ & 4.54 & 4.62 & 0.00 \\
\hline \multirow[t]{2}{*}{ HCM-4x-1 } & 1 & $4 \mathrm{x}$ & 7.00 & 5.75 & 17.86 \\
\hline & 2 & $4 \mathrm{x}$ & 7.00 & 5.97 & 14.71 \\
\hline \multirow[t]{2}{*}{ HCM-4x-2 } & 1 & $4 \mathrm{x}$ & 7.00 & 5.67 & 19.00 \\
\hline & 2 & $4 \mathrm{x}$ & 7.00 & 5.90 & 15.77 \\
\hline \multirow[t]{2}{*}{ HCM-4x-3 } & 1 & $4 \mathrm{x}$ & 7.00 & 5.81 & 17.00 \\
\hline & 2 & $4 \mathrm{x}$ & 7.00 & 5.88 & 16.00 \\
\hline HCM-4x-4 & 1 & $4 \mathrm{x}$ & 7.00 & 5.78 & 17.43 \\
\hline \multirow[t]{2}{*}{ HCM-5x-1 } & 1 & $5 \mathrm{x}$ & 6.92 & 6.16 & 10.98 \\
\hline & 2 & $5 x$ & 6.92 & 5.92 & 14.45 \\
\hline HCM-5x-2 & 1 & $5 \mathrm{x}$ & 6.92 & 6.28 & 9.25 \\
\hline HCM-5x-3 & 1 & $5 x$ & 6.92 & 6.04 & 12.72 \\
\hline \multirow[t]{2}{*}{ 'Paraíso' } & 1 & $6 x$ & 9.29 & 7.86 & 15.39 \\
\hline & 2 & $6 x$ & 9.29 & 7.11 & 23.47 \\
\hline \multirow[t]{2}{*}{ HCM-6x-1 } & 1 & $6 x$ & 9.29 & 8.46 & 8.93 \\
\hline & 2 & $6 x$ & 9.29 & 6.84 & 26.37 \\
\hline \multirow[t]{2}{*}{ HCM-6x-2 } & 1 & $6 x$ & 9.29 & 6.70 & 27.88 \\
\hline & 2 & $6 x$ & 9.29 & 9.03 & 2.80 \\
\hline
\end{tabular}

HCM, hybrid between elephant grass and pearl millet. 


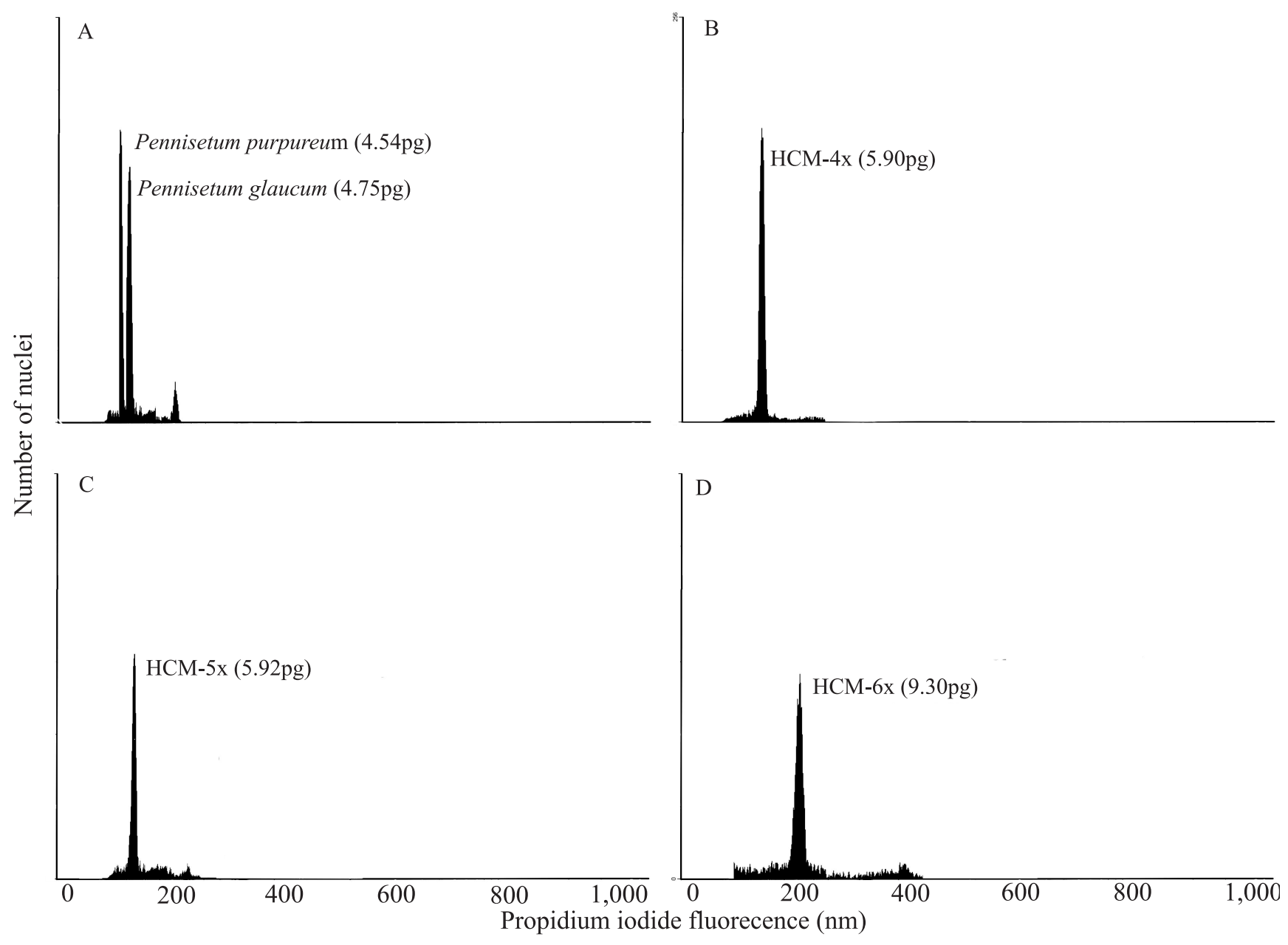

Figure 2. Histograms obtained by flow cytometry of nuclei isolated from leaves: A, Pennisetum purpureum with $4.54 \mathrm{pg}$ of DNA and P. glaucum with $4.75 \mathrm{pg}$ of DNA; B, repetition 2 of genomic combination HCM-4x-2 with 5.90 pg of DNA; C, repetition 2 of genomic combination HCM-5x-1 with 5.92 pg of DNA; D, repetition 2 of genomic combination HCM-6x-2 with $9.03 \mathrm{pg}$ of DNA.

\section{Conclusions}

1. Genomic combinations $4 \mathrm{x}$ and $5 \mathrm{x}$ are mixoploid, and the variation of chromosome number within chromosomal race $5 \mathrm{x}$ is greater than in $4 \mathrm{x}$.

2. Genomic changes occur in chromosomal race $4 x$, which lead to higher reduction in DNA amount when compared to $5 \mathrm{x}$.

\section{Acknowledgements}

To Fundação de Amparo à Pesquisa do Estado de Minas Gerais, to Conselho Nacional de Desenvolvimento Científico e Tecnológico, and to Coordenação de Aperfeiçoamento de Pessoal de Nível Superior, for financial support.

\section{References}

ABREU, J.C. de; DAVIDE, L.C.; PEREIRA, A.V.; BARBOSA, S. Mixoploidia em híbridos de capim-elefante $\mathrm{x}$ milheto tratados com agentes antimitóticos. Pesquisa Agropecuária Brasileira, v.41, p.1629-1635, 2006.

ADAMS, K.L.; WENDEL, J.F. Polyploidy and genome evolution in plants. Current Opinion in Plant Biology, v.8, p.135-141, 2005.

ANDRADE-VIEIRA, L.F. Comportamento genômico em híbridos de capim-elefante e milheto (Pennisetum sp. Schum., Poaceae). 2010. 123p. Tese (Doutorado) - Universidade Federal de Lavras, Lavras.

BARBOSA, S.; DAVIDE, L.C.; PEREIRA, A.V.; ABREU, J.C. de. Duplicação cromossômica de híbridos triplóides de capim-elefante e milheto. Bragantia, v.66, p.365-372, 2007.

BUSTAMANTE, F.O. Variações cromossômicas associadas à poliploidização em híbridos de Pennisetum spp.: um estudo 
temporal e tecido específico. 2009. 53p. Dissertação (Mestrado) Universidade Federal de Lavras, Lavras.

CAMPOS, J.M.S.; DAVIDE, L.C.; SALGADO, C.C.; SANTOS, F.C.; COSTA, P.N.; SILVA, P.S.; ALVES, C.C.S.; VICCINI, L.F.; PEREIRA, A.V. In vitro induction of hexaploid plants from triploid hybrids of Pennisetum purpureum and Pennisetum glaucum. Plant Breeding, v.128, p.101-104, 2009.

CAPERTA, A.D.; DELGADO, M.; RESSURREIÇÃO, F.; MEISTER, A.; JONES, R.N.; VIEGAS, W.; HOUBEN, A. Colchicine-induced polyploidization depends on tubulin polymerization in c-metaphase cells. Protoplasma, v.227, p.147-155, 2006.

COMAI, L. Genetic and epigenetic interactions in allopolyploid plants. Plant Molecular Biology, v.43, p.387-399, 2000.

DOLEŽEL, J. Application of flow cytometry for the study of plant genomes. Journal of Applied Genetics, v.38, p.285-302, 1997.

DOLEŽEL, J.; GREILHUBER, J.; SUDA, J. Estimation of nuclear DNA content in plants using flow cytometry. Nature Protocols, v.2, p.2233-2244, 2007.

DOYLE, J.J.; FLAGEL, L.E.; PATERSON, A.H.; RAPP, R.A.; SOLTIS, D.E.; SOLTIS, P.S.; JONATHAN, F.; WENDEL, J.F. Evolutionary genetics of genome merger and doubling in plants. Annual Review of Genetics, v.42, p.443-461, 2008.

GERNAND, D.; RUTTEN, T.; VARSHNEY, A.; RUBTSOVA, M.; PRODANOVIC, S.; BRÜB, C.; KUMLEHN, J.; MATZK, F.; HOUBEN, A. Uniparental chromosome elimination at mitosis and interphase in wheat and pearl millet crosses involves micronucleus formation, progressive heterochromatinization, and DNA fragmentation. Plant Cell, v.17, p.2431-2438, 2005.

LAURIE, D.A.; BENNETT, M.D. The timing of chromosome elimination in hexaploid wheat $\mathrm{x}$ maize crosses. Genome, v.32, p.953-961, 1989.

LEÃO, F.F. Citogenética e potencial forrageiro de combinações genômicas de capim-elefante e milheto. 2009. 112p. Tese (Doutorado) - Universidade Federal de Lavras, Lavras.
LEVY,A.A.; FELDMAN, M. Genetic and epigenetic reprogramming of the wheat genome upon allopolyploidization. Biological Journal of the Linnean Society, v.82, p.607-613, 2004.

MA, X.-F.; FANG, P.; GUSTAFSON, J.P. Polyploidization-induced genome variation in triticale. Genome, v.47, p.839-848, 2004.

MA, X.-F.; GUSTAFSON, J.P. Timing and rate of genome variation in triticale following allopolyploidization. Genome, v.49, p.950-958, 2006.

MOCHIDA, K.; TSUJIMOTO, H.; SASAKUMA, T. Confocal analysis of chromosome behaviour in wheat $\mathrm{x}$ maize zygotes. Genome, v.47, p.199-205, 2004.

OZKAN, H.; TUNA, M.; ARUMUGANATHAN, K. Nonadditive changes in genome size during allopolyploidization in the wheat (Aegilops-Triticum) group. Journal of Heredity, v.94, p.260-264, 2003.

PELLICER, J.; GARCIA, S.; CANELA, M.Á.; GARNATJE, T.; KOROBKOV, A.A.; TWIBELL, J.D.; VALLÈS, J. Genome size dynamics in Artemisia L. (Asteraceae): following the track of polyploidy. Plant Biology, v.12, p.820-830, 2010.

PEREIRA, A.V.; SOUZA SOBRINHO, F. de; SOUZA, F.H.D. de; LÉDO, F.J. da S. Tendências do melhoramento genético e produção de sementes forrageiras no Brasil. In: SIMPÓSIO DE ATUALIZAÇÃO EM GENÉTICA E MELHORAMENTO DE PLANTAS, 7., 2003, Lavras. Anais. Lavras: UFLA, 2003. p.36-63.

RIDDLE, N.C.; BIRCHLER, J.A. Effects of reunited diverged regulatory hierarchies in allopolyploids and species hybrids. Trends in Genetics, v.19, p.597-600, 2003.

SCHOENLEIN, P.V.; BARRETT, J.T.; KULHARYA, A.; DOHN, M.R.; SANCHEZ, A.; HOU, D.-Y.; MCCOY, J.B.S. Radiation therapy depletes extrachromosomally amplified drug resistance genes and oncogenes from tumor cells via micronuclear capture of episomes and double minute chromosomes. International Journal of Radiation Oncology, v.55, p.1051-1065, 2003.

TECHIO, V.H. Meiose e análise genômica em Pennisetum spp. 2002. 104p. Tese (Doutorado) - Universidade Federal de Lavras, Lavras.

$\overline{\text { Received on March 15, } 2011 \text { and accepted on June 2, } 2011}$ 